Något om prisstegring, inflation och valutapolitik

Author(s): Bertil Ohlin

Source: Ekonomisk Tidskrift, Årg. 23, häft 3 (1921), pp. 55-69

Published by: Wiley on behalf of The Scandinavian Journal of Economics

Stable URL: http://www.jstor.org/stable/3472435

Accessed: 27-06-2016 05:13 UTC

Your use of the JSTOR archive indicates your acceptance of the Terms \& Conditions of Use, available at

http://about.jstor.org/terms

JSTOR is a not-for-profit service that helps scholars, researchers, and students discover, use, and build upon a wide range of content in a trusted digital archive. We use information technology and tools to increase productivity and facilitate new forms of scholarship. For more information about JSTOR, please contact support@jstor.org.

Wiley, The Scandinavian Journal of Economics are collaborating with JSTOR to digitize, preserve and extend access to Ekonomisk Tidskrift 


\title{
Något om prisstegring, inflation och valutapolitik.
}

\author{
Av Bertil Ohlin.
}

Närmaste anledningen till denna uppsats är prof. Davidsons intressanta undersökning över "Valutaproblemets teoretiska innebörd", ${ }^{\text {I }}$ som föranledde mig att göra ett par reflexioner över närliggande problem. Av denna anledning väljer jag Davidsons analys som utgångspunkt för den följande framställningen, ehuru jag icke har något väsentligt att invända mot de resultat, till vilka han under sina förutsättningar kommer.

D. behandlar fyra olika fall av prisstegring och finner, att endast den prisstegring som uppträtt i samband med rubbningar i penningväsendet, men utan minskning av varumängd $o$. d. är att anse som skadlig, medan däremot prisstegring i fall av varubrist, accisbeskattning och monopolistisk exploatering är att föredraga framför konstant prisnivå.

Som exempel på det första nämnes, att penningräntan hålles för låg, vilket leder till en helt och hållet onödig prisstegring, medförande förändringar bl. a. av inkomst- och förmögenhetsfördelningen. En dylik prisstegring bör alltså förhindras.

Det andra fallet, varubrist, skall jag här ägna en mera utförlig behandling.

\section{Prisstegring vid varubrist.}

För att få ett svar på frågan om även i detta fall konstant prisnivå är det önskvärda konstruerar D. en situation, som visserligen knappast kan uppkomma $\mathrm{i}$ verkligheten, men som till gengäld i högsta grad förenklar resonemanget. "I detta andra fall antages sålunda att allt forblivit oforändrat utom att landets produktivitet och därigenom nationalprodukten minskats, och att i samband därmed en mot denna minskning svarande allmän varuprisstegring inträtt, under det att penningväsendet förblivit orört. ${ }^{2}$ Resultatet av undersökningen blir följande:

s Ekonomisk Tidskrift, h. 3-4, 1920.

2 A. a. sid. 74. Kurs av B. O. Innefattar bl. a. antagandet, att varornas relativa priser trots varubristen förblivit oförändrade.

5-21125. Ekonomisk Tidskrift I921. Häft. 3 . 
"Stiger prisnivån så, att nationalproduktens penningvärde förblir oförändrat, behöves och sker ej någon omjustering av de enskildes penninginkomster, så att någon förskjutning $\mathrm{i}$ inkomst- och förmögenhetsfördelningen ej inträder som följd av varuprisstegringen. Verkan av prisstegringen blir, att en penninginkomst av given storlek representerar mindre mängd realnyttigheter än förut, men denna verkan träffar alla innehavare av penninginkomster i lika grad.»

"Den allmänna prisstegringen i detta fall är sålunda icke omotiverad såsom i första fallet, utan tjänar ett positivt och gott ändamål.» ${ }^{x}$

Denna Davidsons slutsats gäller emellertid endast under hans inskränkande förutsättningar. För att resultatet skall få praktisk betydelse gäller det därför att visa, att under mera sannolika förutsättningar verkan blir densamma, d. v. s. att tillkommande faktorer, t. ex. förändringar av varornas relativa priser ej medföra någon förändring.

Under sådana omständigheter torde det kunna ifrågasättas, om det ej erbjuder vissa fördelar att som utgångspunkt för resonemanget välja ett slag av varubrist, som faktiskt förekommit utan några inskränkande förutsättningar i fråga om t. ex. förändringar av varornas relativa priser. Just dessa synas mig nämligen få den allra största betydelse för inkomstfördelningen, vilken däremot under D:s förutsättningar förblir oförändrad. Klart är att varubristen måste bliva mycket olika på olika varumarknader och i varje fall på grund av efterfrågans olika elasticitet måste medföra förändringar av de relativa priserna, vilket å sin sida direkt måste medföra vinster för en del befolkningskategorier och förluster för andra. Dessutom har produktionen en tendens att kasta sig på de områden, som löna sig bäst med övergivande av de mindre lönande. Den ändrade konsumtionsriktningen framtvingar således en produktionsomläggning, som i sin tur leder till ökad efterfrăgan efter de varuslag, som tjäna produktionen av de mest efterfrågade artiklarna. Allt synes mig under sådana förhållanden tala för att en förändring av inkomstfördelningen kommer till stånd, $\mathrm{i}$ det stora vinster hopas på några händer, medan andra få bära större delen av prisstegringens börda.

Som professor Heckscher påpekat för mig, är allt detta visserligen principiellt sett blott att beteckna som rubbningsfenomen och förändringen av inkomstfördelningen alltså övergående, men detta har för mitt resonemang ganska ringa betydelse. Förskjutningarna av varornas relativa priser torde nämligen i praktiken bliva mycket långvariga på grund av det ekonomiska livets friktion (jfr det fasta kapitalets betydelse), vilken förhindrar en snabb utjämning genom överförande av produktionskrafter till de nu mer än förr knappa varornas produktion. De faktorer, som framkallat varuknappheten på vissa marknader, torde sålunda i de flesta tänkbara

A. a. sid. 78 . 
fall hava förändrats till antal och styrka, långt innan denna friktion övervunnits, varför det förefaller mycket osannolikt, att prisstegringen får tillfälle bliva likformig, innan nya förändringar göra sig gällande.

Men även om man frånser dessa rubbningar, vad man dock enligt min mening ej har rätt att göra, om man vill nå resultat av praktisk betydelse, så kommer likväl en förändring av inkomstfördelningen, och alltså en bestående sådan, med största sannolikhet till stånd, i det följden av den ändrade varuförsörjningen, $t$. ex. vid en partiell avstängning från utlandet, även sedan det nya jämviktsläget uppnåtts, troligen blir en förskjutning av de olika produktionsfaktorernas relativa knapphet. Närmast till hands ligger här att tänka på att de tusentals olika naturtillgångar, som innefattas $\mathrm{i}$ begreppet jord, komma att bliva delvis mera, delvis mindre knappa än förr. Vidare förefaller en ändring av knappheten på vissa slag av arbetskraft och på kapital ej osannolik, ehuru man utan närmare preciserade förutsättningar saknar möjlighet att uttala sig bestämt därom.

Det är emellertid tänkbart, ehuru föga sannolikt, att dylika förändringar av produktionskrafternas relativa knapphet utebliva, varför man med bortseende från rubbningsfenomenen skulle få till resultat oförändrad inkomstfördelning; detta gäller dock endast approximativt, ty rubbningsfenomenen kunna näppeligen undgå att draga med sig bestående förändringar, något som man vid uteslutande behandling av jämviktslägen har lätt att bortse ifrån. Jag behöver endast peka pả en sådan omständighet, som att den tillfälliga förändringen av inkomstfördelningen skapar en bestående förändring av förmögenhetsfördelningen och därmed även en bestående förändring av inkomstfördelningen i framtiden; de personer, som gjort stora vinster och sparat en del av dessa, få ju i framtiden ökade ränteinkomster.

För min del är jag böjd att, särskilt med tanke på avspärrning från utlandet, fästa störst vikt vid själva rubbningsfenomenen och dessas omedelbara verkningar, då man i detta fall av varubrist synes mig ha att motse ständigt nya rubbningar, ända till dess normal varutillgång ånyo inträtt, och alltså aldrig kommer att uppnå något jämviktsläge under varuknapphetens tid.

En plötslig och bestående minskning av en produktionsfaktor (jfr 8-timmarsdagen) kan däremot bliva orsak till en situation av varuknapphet, där ett dylikt jämviktsläge verkligen uppnås och, ceteris paribus, bibehålles. I detta fall ligger emellertid en förändring av de relativa varupriserna och inkomstfördelningen i sakens natur.

Om således, även när prisstegringen hålles inom de av oförändrad total penninginkomst d. v. s. konstant cirkulation betingade gränserna, en ändring av inkomstfördelningen och betydande rubbningar inom det ekonomiska livet med all sannolikhet komma att inträffa som följd av varubris- 
ten, så uppställer sig frågan, vid vilken prisnivå dessa störningar bliva minst, ty då de i allmänhet äro skadliga, blir ju denna prisnivå målet för penningpolitiken. Att om nationalprodukten bibehålles vid oförändrat penningvärde, penninginkomsternas summa förblir oförändrad, medan man för att uppnå en lägre prisnivå tvingas att företaga en större eller mindre sänkning av denna summa, talar därvid måhända för det förra alternativet, då löneförändringar utan tvivel äro mycket svårare att åstadkomma än ändringar i varuprisen. Emellertid undgår man som nämnts ingalunda höjningar och sänkningar av inkomsterna inom olika yrken. Tag som exempel en situation med utebliven eller minskad råvaruimport. Om förhållandena gestalta sig som under kriget, måste driften då på många håll inskränkas, ja kanske nedläggas, vilket leder till minskade inkomster för arbetare, aktieägare $\mathrm{m}$. $\mathrm{fl}$. Att inkomstökningen inom andra industrier håller sig vid mindre proportioner än denna sänkning, torde i så fall ej utan vidare kunna anses skadligt, ehuru det skulle leda till en minskning av den totala penninginkomsten och därmed till en sänkning av nationalproduktens penningvärde, d. v. s. en mindre prisstegring än som svarar mot varumängdens kvatitativa minskning. Ej heller torde den tillfälliga förändringen av förmögenhetsfördelningen kunna anses som ett stort ont; den går ju tillbaka, när varubristen upphört, vilket väl $\mathrm{i}$ regel ej dröjer så många år. (Antager man en bestående varubrist, blir saken $i$ viss mån en annan.) Härmed är ej sagt, att en sänkning av produktionsvärdet verkligen skulle vara att föredraga framför konstant penningmängd och konstant total penninginkomst, utan jag har endast velat visa, att om man ej tager hänsyn till de förändringar av inkomstfördelningen, som med all sannolikhet följa med varubristen, så kan det ej anses konstaterat, att oförändrad total penninginkomst, resp. konstant penningcirkulation bör sättas som målet för den praktiska valutapolitiken. Hur denna fråga, vilken prisnivå som är den fördelaktigaste vid varubrist, verkligen skall kunna med någorlunda tillförlitlighet lösas, kan jag för min del ej se. Troligt är väl, att någon generell lösning ej existerar, utan att resultatet blir beroende på omständigheterna i varje särskilt fall.

Icke desto mindre torde en undersökning över varubristens verkningar i olika avseenden vara av intresse för valutapolitiken. Dessvärre tilllåter förutsättningarnas ofrånkomliga obestämdhet ej någon djupare analys. På en punkt torde emellertid någon ytterligare belysning vara möjlig, nämligen beträffande frågan om varuknapphetens inverkan på den normala kapitalräntan, vilken fråga ju har den allra största betydelse för diskontopolitiken. Varuknappheten antages härvid hava uppkommit dels direkt genom att inporten minskats, dels indirekt genom att den normala importen delvis utgjorts av produktionsmedel för industrien, och således importminskningen framkallat en sänkning av dennas produktivitet. 
Den sannolika följden av varuknappheten blir, som redan nämnts, betydande förändringar $\mathrm{i}$ varornas relativa priser, detta dels därför, att bristen måste bliva mycket ojämn - störst på de områden, där vi äro mest beroende av utlandet - dels därför att efterfrågan efter olika varor är av så olika elasticitet.

Ju större bristen på en vara blir, dess mer stiger dess pris, och dess starkare blir incitamentet att upptaga, resp. öka redan existerande, inhemsk tillverkning. I de fall, då utländska råvaror ej spela någon större roll, går detta mycket väl för sig. Skulle åter de utländska råvarorna vara nödvändiga, kan bristen på dessa medföra icke blott att produktiviteten i branschen minskas, utan även att en del företag nedlägga driften. Under sådana förhållanden kommer emellertid med största sannolikhet tillverkningen av allehanda surrogatartiklar att bliva lönande. I båda fallen kommer därför en kraftig tendens till nyanläggningar och utvidgningar av fabriker, nyanskaffning av maskiner $\mathrm{m}$. $\mathrm{m}$. att göra sig gällande, vilket innebär en ökning av efterfrågan på kapital, som endast $\mathrm{i}$ mycket ringa grad torde kunna uppvägas av ökad tillgång på kapital frăn de industrier, som blivit mindre lönande. Det moderna produktionssättet utmärkes nämligen framför allt av kapitalets bundenhet, den stora användningen av s. k. fast kapital; ett frigörande av kapital från en mindre lönande produktion blir därför ytterst svårt och kan ske endast $\mathrm{i}$ ringa utsträckning, åtminstone om man tar $\mathrm{i}$ betraktande endast en kortare tidsperiod, t. ex. ett par år. Även i de fall, där ett frigörande av kapital i större eller mindre utsträckning kunde komma till stånd, är det emellertid ej säkert, att så kommer att ske. Företagsledarna betrakta nämligen, och ofta med rätta, den dåliga räntabiliteten endast som ett övergående fenomen och äro därför ej böjda för en definitiv inskränkning av produktionen. Understundom kunna de t. o. m. börja arbeta på lager i hopp om bättre priser $\mathrm{i}$ framtiden och på så sätt taga i anspråk mera kapital än normalt. Det torde således vara klart, att det kapital som behövs för utvidgning och nyanläggningar inom de produktionsområden, som plötsligt blivit lönande, ej kan tagas från de produktionsområden, som blivit oräntabla. Emot ökningen av efterfrågan svarar intet ökat utbud.

Det kan inom parentes anmärkas, att denna det kapitalistiska produktionssättets bristande rörlighet är en omständighet, som även vid de under tider av normal varutillgång nödvändiga omläggningarna av produktionen är ägnad att öka knappheten på kapital. Skillnaden är blott den, att omläggningen då försiggår långsammare och därför smidigare.

Det är ej nog med den nu berörda orsaken till ökad kreditefterfrågan vid varubrist, utan härtill kommer i många fall en annan, av analog natur. En företagsledare, som under normala förhållanden har ett råvarulager på t. ex. IOO,000 kr. motsvarande 3 månaders förbrukning, varav 
hälften äro utländska, finner, om priset på dessa senare tredubblas, kanske lämpligt att inskränka inköpen ej till en tredjedel, utan t. ex. till två tredjedelar. Detta innebär att nu $100,000 \mathrm{kr}$. i stället för 50,000 åtgå för inköp av utländska råvaror, under det att som förr ungefär 50,000 användas för inköp av inhemska. I stället för I00,000 kr. behöver han således 150,000 och måste således öka sin kredit med 50,000 kr. Under förutsättning att ej denna kredit lämnas av utlandet för hela den tid som åtgăr för fabrikationen, blir således följden ökade anspråk på den inhemska kapitalmarknaden.

Förutsättningen för en utveckling i denna riktning är tydligen oelastisk efterfrågan. Denna förutsättning torde emellertid ej sällan vara uppfylld beträffande råvaror, då en industriidkare, hellre än att inskränka driften, ökar sin kredit för att kunna inköpa tillräckligt med råvaror. Man har nämligen förenad efterfrågan från konsumenterna efter alla produktionselementen. Vid minskad tillgång på ett av dessa fås då ofta ringa elasticitet hos efterfrågan efter detta.

Det är emellertid ej säkert, att lagerbehållningen skall variera parallellt med förbrukningen. Om än förbrukningen av utländska råvaror förblir vid två tredjedelar av den normala kvantiteten, behöver likväl lagrets genomsnittliga storlek icke hållas vid precis två tredjedelar utan kan sjunka till en tredjedel eller mindre, liksom det kan hållas vid det normala eller t. o. m. ökas. Vid första påseendet förefaller det naturligt, att varuknapphet framkallar minskad lagerbehållning, men detta torde ej med nödvändighet bliva fallet. Om företagarna räkna med, att knappheten skall ökas, uppkommer tvärtom en tendens att $\mathrm{i}$ tid förse sig med lager för så lång tid framåt som möjligt, vilket kan leda till ökning icke blott av enstaka företags utan även av den totala lagerhållningen; den spekulativa prisstegringen kan nämligen minska förbrukningen mera än tillförseln avtagit. Dylik varulagring anser Davidson vara en orsak till självständig prisstegring i en situation av inflation under normal varutillgång, medan däremot vid hans andra fall, varubrist, spekulation av denna art ej uppkommer. ${ }^{x}$ Detta är enligt min mening oriktigt. Allt beror nämligen på om varuknappheten kan väntas bliva övergående eller tillväxa. Att en långvarig minskning av råvarutillförseln $\mathrm{i}$ längden leder till minskad lagerhållning ligger dock i sakens natur. Under utvecklingens första stadier, vilka här i första hand havas i sikte, kan emellertid resultatet lika väl bliva ökning som minskning. Skulle det förra bliva fallet eller skulle lagret minskas procentuellt mindre än förbrukningen, d. v. s. motsvara flera dagars förbrukning än förr, så innebär detta en ny anledning till ökad kreditefterfrågan till de två förut nämnda.

En fjärde orsak skulle kunna nämnas, nämligen starkare behov av konsumtionskredit. Denna står emellertid i det intimaste samband med

\footnotetext{
I Jfr citat å nästa sida.
} 
den orsak till minskat utbud av kapital, som nu skall beröras, och behöver därför ej undersökas separat.

Varubristen och prisförhöjningen medföra med nödvändighet en minskad behovstillfredsställelse för ögonblicket. Om då samma penningbelopp som vanligt sparas, skulle detta ju innebära oförändrad behovstillfredsställelse i framtiden, åtminstone subjektivt sett, enär en i samband med varuknapphet stående prisstegring av den stora allmänheten alltid mer eller mindre betraktas som något övergående. Sparandet kommer följaktligen att minskas, och sannolikt $i$ ej oväsentlig grad, ty det minskade sparandet betraktas likaväl som prisstegringen som något tillfälligt, vilket berättigar till ett ännu starkare minskande av avsättningen för de framtida behovens täckande, än som ur andra synpunkter skulle varit eko. nomiskt. Genomsnittsmänniskan väger naturligtvis ej alla dylika skäl för och emot vid sitt handlande, utan detta sker mer eller mindre instinktmässigt. Men anledning synes mig ej föreligga att antaga, att instinkten skulle leda henne fel.

När den ökade efterfrågan efter kapital ställes mot ett minskat utbud, störes jämvikten, och den normala kapitalräntan stiger. ${ }^{x}$ Skall prisstegringen hålla sig inom de av en konstant penningcirkulation betingade gränserna, måste alltså diskontot höjas. Ehuru det är ytterst svårt att yttra sig om proportionerna, torde man dock kunna påstå, att vid en mera betydande varubrist, sådan som vi t. ex. haft under världskriget, en rätt kraftig stegring blir nödvändig. Denna höjning av räntan innebär en förändring av inkomstfördelningen som följd av varubristen, vilket redan tidigare berörts.

Av denna undersökning framgår bl. a., att Davidsons påstående, att prisstegringen $i$ andra fallet visar helt motsatta egenskaper mot i första, om det än är riktigt under hans inskränkande förutsättningar, näppeligen torde gälla $\mathrm{i}$ en situation av varuknapphet, sådan denna enligt min mening med all sannolikhet komme att bliva vid en mer eller mindre fullständig avspärrning från utlandet, liksom $\mathrm{i}$ de flesta andra sannolika fall. D. skriver nämligen, utgående frăn att prisstegringen hållits inom de av oförändrad total penninginkomst betingade gränserna. "Även övriga verkningar av en inflation utebli $\mathrm{i}$ detta avseende. Minskningen av produktiviteten är ju i sig ägnad att hämma företagsamheten; prisstegringen är blott ett medel att hejda denna verkan. Någon spekulation med fortgående prisstegring och extra ansatser blir ej följden utan prisstegringen har sitt mått i minskningen av produktiviteten.» Tager man hänsyn till

I Denna höjning av kapitalräntan är tydligen delvis att anse som ett rubbningsfenomen, ehuru såvitt jag kan se av lång varaktighet. Att en del av höjningen blir bestånde, när och om ett jämviktsläge uppnås, förefaller med hänsyn till de med omläggningen förbundna kapitalförlusterna ganska sannolikt. 
de förändringar inom näringslivet med avseende på produktion, inkomstfördelning och priser, som nyss utvecklats, blir resultatet ett annat och mera överensstämmande med verkningarna av inflation vid normal varutillgång. Företagsamheten kommer även att livas, ehuru livaktigheten vid varubrist ej kommer att bliva så jämnt fördelad som då. Likaledes kan spekulation och varulagring bliva följden. Huruvida ständigt nya ansatser till prisstegring komma att göra sig gällande, beror i båda fallen på diskontopolitiken.

Något direkt motsatsförhållande mellan de två fallen, sådant som det Davidson lyckats konstruera fram genom valet av förutsättningar, torde således under förutsättningar, som synas mig närmare motsvara verkligheten, ej existera. $\AA$ andra sidan ligger ju i varumarknadens olika utseende många anledningar till olika verkningar $\mathrm{i}$ de mest skilda avseenden, varför ej heller Cassels påstående, att "till sin verkan är denna sänkning (av penningvärdet) alldeles densamma som i föregående fall», såvitt jag kan se är fullt korrekt.

\section{Prisstegring vid accisbeskattning och monopol.}

Davidson undersöker, som redan nämnts, icke blott de två ovan behandlade fallen av prisstegring utan ytterligare två, som han anser vara till sin natur fullkomligt skilda från de förra, nämligen prisstegring på grund av accisbeskattning och på grund av monopolistisk exploatering. I båda dessa fall är enligt Davidsons mening prisstegringen naturlig och nyttig, då en fixering av prisnivån icke skulle förändra det reala i processen, beskattningen resp. exploateringen, utan endast skulle dessutom föra med sig en del för prissänkning i allmänhet typiska verkningar.

Vid första påseendet verkar detta något paradoxalt, att trots att minskning av nationalprodukten ej antages föreligga, likväl en prisstegring skulle vara önskvärd. Man skulle således hava någon sorts "undantag" från regeln i Davidsons första fall, vars viktigaste förutsättning var oförändrad produktion. Emellertid torde saken kunna konstrueras på ett annat sätt, så att det paradoxala till största delen bortfaller. Vad först accisbeskattningen beträffar, så synes det mig kunna ifrågasättas, om det verkligen är lämpligt att beteckna verkan som en stegring av prisnivån. Fattar man skattekvittona som bevis på betalning för de tjänster staten gör den enskilde, intaga de såvitt jag förstår samma ställning, som kvitto på erlagd hyresavgift, gasavgift $\mathrm{m}$. $\mathrm{m}$. och böra således teoretiskt sett tagas med i beräkningen vid uppgörande av prisindex, och detta alldeles oberoende av om skatten uttages direkt eller genom acciser. I så fall kommer emellertid en ökning av den indirekta beskattningen icke att inregistreras $i$ prisindexet mera än en motsvarande ökning av den 
direkta beskattningen. Antager man att den ökade beskattningen innebär, att staten gratis tillhandahåller tjänster, som förut mot betalning utförts av enskilda (resp. som träda i stället för andra sådana), uppkommer $\mathrm{i}$ intetdera fallet någon stegring av prisnivån. Vid den indirekta beskattningen förefaller det som om en del varor och tjänster vore dyrare, medan andra bliva billigare eller tillhandahållas gratis. Vid den direkta beskattningen däremot utgör skatten betalning för prisnedsättningen, resp. för gratisutdelningen av vissa tjänster, men å andra sidan inträder ingen fördyring av andra tjänster eller varor. Antag t. ex. att gasen vid inrättandet av ett kommunalt gasverk säljes under produktionskostnaderna, d. v. s. billigare än förut. $\mathrm{Om}$ nu kostnaderna härför uttagas genom en direkt skatt eller genom en accis på t. ex. biografbiljetterna, spelar detta väl ingen roll för prisnivån, frånsett att accisen drabbar vissa personer hårdare än den direkta skatten.

Det förekommer emellertid också fall, då någon dylik motprestation från statens sida ej lämnas, t. ex. då pengarna användas för att bygga pansarbàtar. I detta fall torde saken kunna konstrueras så, att en del produktionskrafter reserverats för framställning av varor (pansarbåtar), som ej utbjudas på marknaden. För denna kommer i betraktande blott den mindre mängd varor, som med de återstående produktionskrafterna kan framställas. Ur marknadssynpunkt, d. v. s. för prisbildningen, föreligger således en fullständig analogi till ett fall med minskad produktion, varför behandlingen ur valutapolitisk synpunkt även torde böra överensstämma.

Något annorlunda ligger frågan i D:s fjärde fall, den monopolistiska kvasi-beskattningen, varvid antages, att totalproduktionens storlek förblivit oförändrad, ${ }^{\mathrm{T}}$ då annars en kombination med andra fallet föreligger. Det förefaller mig då naturligast att betrakta prisstegringen på monopolvarorna som en vanlig höjning av prisnivån, då någon sänkning av andra priser ej torde inträffa. Vid monopolprisbildning föreligger således ett verkligt undantag från regeln, att vid normal varutillgång höjning av prisnivån ej är önskvärd.

I praktiken förekommer nog detta fall ej isolerat, utan i regel tillsammans med det andra fallet, produktionsminskning; den minskade avsättningen av monopolvarorna kommer nämligen knappast att medföra ett omedelbart överflyttande $\mathrm{i}$ full omfattning av produktionskrafter till andra produktionsområden; analogt torde bliva fallet vid accisbeskattning. Men för att underlätta resonemanget torde det vara berättigat att som här ovan behandla var sak för sig.

I Genom att produktionskrafterna överflyttas från framställning av monopolvaran till framställning av andra. Obestämdheten hos begreppet: oförändrad produktionskvantitet synes icke kunna avhjälpas. Den torde vara av samma slag som hos begreppet: oförändrad kapitalkvantitet vid ändring av produktionsriktningen. 
Efter att hitintills hava behandlat frågan $\mathrm{i}$ vad mån prisstegring $\mathrm{i}$ olika fall kan vara önskvärd och dennas dimensioner övergår jag nu till en knapphändig belysning av problemet, hur man i praktiken skall kunna bedöma, i vad mån prisstegringen har de dimensioner, som man i olika fall anser vara lämpligt.

\section{Prisstegringens förhållande till cirkulationsökningen.}

Klart är att en statistisk uppskattning av nationalproduktens pen. ningvärde icke tillräckligt snabbt och kanske ej heller tillräckligt noggrant kan genomföras, för att den skall kunna tjäna som ledtråd för valutapolitiken. Man måste därför söka efter indicier, som ungefärligt angiva produktionsvärdets förändringar. Det lämpligaste torde då vara penningcirkulationen, detta begrepp fattat i dess vidaste betydelse. En förändring av denna $i$ viss riktning bör nämligen, frånsett en del mindre betydande undantag, angiva en motsvarande förändring av nationalproduktens penningvärde. Vill man gå ännu längre på förenklingens väg skulle man, under antagande att omloppshastigheten är konstant under kortare tidsperioder, kunna gå efter "penningmängdens" förändringar, vilka ju äro relativt lätta att snabbt konstatera. Utgår man ifrån, att vid varubrist ett bibehållande av nationalprodukten vid oförändrat penningvärde är det önskvärda, något som jag på ovan anförda skäl ej anser vara givet, men som man måhända $\mathrm{i}$ den praktiska valutapolitiken i brist på annan ledtråd får utgå ifrån, skulle således oförändrad penningmängd vara det naturliga, utom vid monopol och vissa fall av accisbeskattning, medan däremot vid dessa någon ökning av penningmängden skulle vara önskvärd såsom uttryck för en stegring av nationalproduktens penningvärde. (Jfr ovan ang. det tredje fallet.)

Denna slutsats torde emellertid kräva ytterligare belysning, varför jag skall något undersöka verkningarna med avseende på penningmängden i monopolfallet.

Olika alternativ äro helt naturligt tänkbara, allt efter allmänhetens och affärsmännens sätt att reagera. Gemensamt för dem alla synes mig emellertid bliva, att den enligt antagande oförminskade totala varumängden omsättes som förut, utom att vid försäljningen av monopolvarorna dessutom en överflyttning av köpkraft från monopolister till konsumenter äger rum. ${ }^{x}$ Då någon anledning att antaga ökad omloppshastighet hos omsättningsmedlen $\mathrm{i}$ proportion till omsättningens tillväxt icke torde finnas, måste en ökning av dessas kvantitet äga rum. Detta kan ske på flera olika sätt; antag t. ex. monopolisterna omedelbart vid mono-

I I detta resonemang antages, att någon förändring av landẹts totala sparande på grund av monopolets uppkomst ej inträffar. 
polets uppkomst vilja använda sin monopolvinst successivt, alltefter som den av allmänheten inbetalas till detaljhandlarna, ${ }^{x}$ vilket betyder att avsättningen av övriga varor och dessas pris blir oförändrad. I så fall måste antingen detaljhandlarna vid inköp betala monopolvarorna kontant och således förskottera monopolvinsten, vilket innebär att de bliva i behov av ökade banklån, eller också monopolisterna upptaga lån i bankerna och sälja på kredit. Under alla förhållanden strömmar en viss mängd betalningsmedel ut från bankerna, mindre ju snabbare monopolvinsten överflyttas från allmänheten till monopolisterna. Av vikt är därvid att konstatera, att den förändring av omsättningsapparaten som inträffat är av rent teknisk och formell natur, vilket bäst illustreras därav, att medan jämvikten på den reala kapitalmarknaden aldrig störts, kommer jämvikten på penningmarknaden att återställas, så fort de nödiga omloppsmedlen strömmat ut ur bankerna.

Oförändrad prisnivå för de icke-monopoliserade varorna och höjda priser å monopolvarorna, d. v. s. ökning av cirkulationen och penningmängden, blir således den naturliga följden, om jämvikten på den reala kapitalmarknaden uppehålles.

Av ovanstående resonemang kan man nu, oberoende av vad i första avdelningen därom anförts, sluta sig till att vid varubrist nationalproduktens bibehållande vid konstant penningvärde icke behöver vara det lämpligaste och icke kommer att bliva följden, om jämvikten på den reala kapitalmarknaden icke rubbas. Allt beror här på vilka förutsättningar man gör rörande varubristens karaktär. En hastigt uppkommande brist på en vara medför för innehavarna en vinst av samma art som en monopolvinst; och vidare: vid begränsning av tillgången av vissa råvaror, $t$. ex. genom exportförbud med licensgivning i ursprungsländerna, åstadkommes en begränsning av tillgången på den färdiga varan liksom vid monopol; producenterna komma i samma ställning som vanliga monopolister. Följden med avseende på priser och cirkulation måste alltså till en början bliva densamma som vid monopol, $\mathrm{d}$. v. s. man får, om diskontot hålles vid den naturliga kapitalräntans höjd, en stegring av nationalproduktens penningvärde och av cirkulationen och penningmängden. Att genom övernormalt diskonto hålla priserna nere på den nivå, som betingas av konstant cirkulation, vore tydligen i detta fall lika litet befogat som vid vanligt monopol. Varubristens förmåga att skapa tillfälliga monopol är således en faktor, som kan och bör framkalla cirkulationsökning vid jämvikt på den reala kapitalmarknaden.

I Se not å föregående sida. 


\section{Inflationsbegreppets omfång och innehåll.}

Begreppsanalyser hava sedan slutet av förra århundradet ganska dåligt ansende inom nationalekonomien, kanske framför allt beroende på ofruktbarheten hos den intensiva diskussionen över kapitalbegreppet. Den mångskiftande terminologi, som allt fortfarande är rådande, måste emellertid utan tvivel anses som en svaghet, då användandet av ett och samma ord i helt olika betydelser hos olika författare lätt leder till missförstånd. Önskvärt vore därför, att något större enhetlighet kunde uppnås. Med hänsyn härtill har jag ansett det vara icke alldeles omotiverat att upptaga ett par sidor med en undersökning över inflationsbegreppet.

Frågan är på vad sätt inflationsbegreppet kan bliva till största nyttan vid en annalys av prisstegring. Närmast till hands torde det ligga att vid klassificeringen av företeelser använda som indelningsgrund deras orsaker och därav betingade egenskaper. För det föreliggande problemet innebär detta t. ex., att prisstegringen skulle uppdelas i två olika klasser, allteftersom dess orsaker äro att söka på "penningsidan" och på "varusidan». Det förra slaget av prisstegring skulle kunna betecknas med termen inflation, då man därigenom skulle komma det allmänna språkbruket ganska nära; detta förknippar väl i regel med ordet inflation en föreställning, att "det är pengarnas fel».

För att närmare klargöra vad denna distinktion innebär, kan det vara lämpligt att skilja på ett par olika fall. Vad först en hastigt inträffande varubrist ceteris paribus beträffar, så torde det kunna sägas, att en prisstegring, som håller sig inom de av en konstant cirkulation (d. v. s. oförändrad "penningsida") betingade gränserna, måste anses vara framkallad av varubristen. Det kan visserligen hända, att en stegring av den normala kapitalräntan blir följden, och att alltså en stegring av diskontot blir nödvändig, för att prisstegringen skall hålla sig inom ovannämnda gräns. När man anser en dylik prisstegring vara framkallad av varubristen, har man alltså förutsatt, att diskontot alltid hålles vid den normala kapitalräntans höjd. Denna förutsättning torde vara berättigad, då det naturliga och givna, när ingenting säges därom, är att alla priser, även kapitalräntan, intaga den ställning, som skapar jämvikt. ${ }^{{ }^{\top}}$ En prisstegring av dessa dimensioner är alltså ej att beteckna som inflation, vilket däremot är fallet med varje prisstegring därutöver; ${ }^{2}$ denna kan nämligen anses framkallad av en penningfaktor, nämligen att diskontot hållits under den normala kapitalräntan. ${ }^{3}$

I Detta har påpekats för mig av prof. Heckscher.

2 Undantag, ehuru utan större praktisk betydelse, inträffa vid monopol, liksom vid av varubristen framkallade kvasimonopol. (Jfr ovan.)

3 Med normal kapitalränta menas här, i likhet med hos Wicksell, den ränta vid 
Helt annorlunda gestaltar sig saken vid en långsamt fortskridande ökning eller minskning av varutillgången, d. v. s. i ett progressivt resp. regressivt samhälle; utan närmare motivering kan man våga påstå, att här en ökning resp. minskning av alla det ekonomiska livets organ, alltså även omsättningsapparaten, är det naturliga. Överflyttat till det stationära betraktelsesättet är detta fall identiskt med konstant varutillgång och konstant cirkulation.

När som "inflation" betecknas den prisstegring, som har sina orsaker på penningsidan och tager sig uttryck i en ökning av cirkulationen, gäller detta alltså blott ett samhälle, som varken tillväxer eller avtager. Generellt kan samma sak utttyckas med att inflationen tager sig uttryck $i$ en ökning av cirkulationen utöver det "normala", d. v. s. den storlek, som betingas av samhällets tillväxt eller avtagande. Vid diskussionen om inflation har man emellertid $\mathrm{i}$ regel så korta tidsperioder $\mathrm{i}$ sikte, att man kan utan olägenhet försumma progressionen resp. regressionen och antaga konstant cirkulation som det normala.

Detta är dock ej fullt korrekt, då man har att taga hänsyn även till de i vårt ekonomiska liv mycket "naturliga» konjunkturväxlingarna; ifråga om dessas förändring av produktion och omsättning torde man emellertid kunna anlägga samma betraktelsesätt som ifråga om samhällets progression och regression. Inflation blir då den prisstegring, som har sina orsaker på penningsidan, d. v. s. tager sig uttryck i en starkare ökning av penningcirkulationen än av varutillgången.

Det torde emellertid kunna ifrågasättas, om man ej gör klokast $i$ att icke använda ordet inflation i sammanhang med konjunkturväxlingarnas prisrörelser utan begränsa dess användning till fall av mera extraordinärt slag. Härigenom vinner begreppet $\mathrm{i}$ klarhet och kommer närmare det allmänna språkbruket.

Att med inflation menas den prisstegring, som har sina orsaker på penningsidan, har här ovan jämställts med att inflation är den prisstegring, som ceteris paribus ${ }^{x}$ tager sig uttryck $i$ en ökning av cirkulationen. Om emellertid ej övriga omständigheter förhållit sig lika, kan inflationens tendens att framkalla ökning av cirkulationen motverkas eller förstärkas av andra faktorers tendens att minska resp. öka denna. Cirkulationens ökning angiver därför ej alltid måttet på inflationen. En livlig fastighetshandel eller omsättning av varorna flera gånger på deras väg till konsumenterna kan t. ex. framkalla en ökning av cirkulationen, utan att inflation föreligger.

vilken tillgången och efterfrågan på kapital väga jämnt. Således samma begrepp som Cassels "richtige Zinsfuss".

${ }^{x}$ Denna förutsättning innehåller som av ovanstående framgår, ej att varumängden förblir oförändrad, men att varuomsättningen fortgår som förut. 
Ett sätt att undgå denna svårighet är att med inflation beteckna den prisstegring, som framkallar en ökning av nationalproduktens penningvärde, alltjämt under förutsättning att samhällets progression och regression under den tidsperiod, som betraktas, kan försummas. Man drager på så sätt varken varornas eller produktionsmedlens omsättning in i resonemanget. Emellertid lider denna definition av den praktiska svagheten, att nationalproduktens penningvärde ej kan statistiskt fastställas med tillräcklig noggrannhet och snabbhet, varför ett bedömande av en viss situation ur inflationssynpunkten icke är möjligt på denna grundval. Härvid tvingas man i stället att taga i betraktande cirkulationens storlek, dock med hänsyn tagen till ovannämnda reservationer.

Vid avgörande av frågan, huru stor del av en viss konstaterad prisstegring som beror på varubrist och huru stor del som beror på penningfaktorer, d. v. s. är att beteckna som inflation, kan man således ej utan vidare gå efter cirkulationens storlek. Trots att denna vuxit t. ex. med $200 \%$ och prisnivån stigit med t. ex. $230 \%$, är det ej alls säkert att blott nivåns höjning från 300 till $330 \%$ är framkallad av varubrist, utan kan denna faktor vara skulden till en större del av prisstegringen och en del av cirkulationsökningen vara beroende på t. ex. varuspekulation, som leder till ökat antal omsättningar av varje varuenhet. Ett konstaterande att cirkulationsökning föreligger samtidigt med prisstegring angiver ej utan vidare inflation; prisstegringen kan nämligen vara framkallad av varubrist och cirkulationsökningen av en annan faktor på varusidan. ${ }^{\mathrm{x}}$

Någon större praktisk betydelse torde detta ej hava, enär varuomsättningen knappast förändras så mycket, att någon mera betydande cirkulationsökning framkallas. Mycket ofta kan därför cirkulationens ökning anses som ett mått på inflationen.

Resultatet av denna undersökning synes mig bliva, att det kan vara lämpligt att med inflation beteckna den prisstegring, som har sina orsaker på penningsidan, d. v. s. framkallas av undernormal räntefot, och som ceteris paribus ${ }^{2}$ tager sig uttryck i en ökning av cirkulationen. Detta inflationsbegrepp torde som nämnts ganska nära ansluta sig till såväl det allmänna språkbruket som till ordets egentliga betydelse, "uppblåsning». Men vare härmed huru som helst, så synes det mig dock innebära företräden framför den av Cassel föreslagna användningen av ordet inflation, vilket skulle likställas med prisstegring i allmänhet, oberoende av om varubrist föreligger eller ej. Detta tillvägagångssätt innebär, förefaller det mig, ett omotiverat slöseri med nationalekonomiens rätt knappa ordförråd. När man kan använda uttrycken, prisnivåns stegring och penningvärdets

"Detta beaktar ej prof. Cassel i "Dyrtid och sedelöverflöd", sid. 2 I.

${ }^{2}$ Se noten å föregående sida. 
fall, är det onödigt att förbruka ytterligare en term för att uttrycka samma sak; däremot kan det vara lämpligt att äga en särskild benämning på den prisstegring, som medför cirkulationsökning. Någon nödvändighet att fastställa begreppet inflation så som Cassel, därför 》att vi icke alltid känna dess orsaker», kan jag ej heller finna.

Pigous tillvägagångssätt ${ }^{\mathbf{x}}$ att skilja på »movements which are, and movements which are not, made possible by overt Government interference with the banking and monetary machine» kan vid första påseendet synas tilltalande, men lider, som Pigou själv påpekar, av två avgörande svagheter. För det första är det omöjligt att $i$ ett visst fall avgöra om och $\mathrm{i}$ huru hög grad en statlig åtgärd inverkat; för det andra är bank- och penninglagstiftningen så olika i olika länder, att en och samma utveckling $i$ det ena landet förutsätter statens medverkan, i det andra däremot icke. Med hänsyn härtill finner Pigou, att det kanske vore bäst att helt och hållet övergiva termen inflation.

Den uppdelning av inflation i direkt och indirekt, som man ej sällan ser använd, synes mig knappast vara motiverad. Den av statsmakten framkallade, s. k. direkta inflationen företer nämligen inga väsentliga avvikande drag från den, som brukar betecknas som indirekt.

Vanligen plägar som karakteristiskt för den förra anföras, att den skapar en känsla av "gott om pengar» i privatbankerna. Detta kan emellertid bliva fallet även vid s. k. indirekt inflation. I själva verket kan skillnaden mellan de under olika omständigheter uppträdande olika slagen av indirekt inflation vara fullt lika stor som mellan direkt och indirekt sådan. Att fästa någon avgörande vikt vid att staten $i$ ena fallet är kredittagare är numera så mycket mindre påkallat, som densamma använder en stor del av det utplånade kapitalet för affärsdrift. Sättet för upplåningen torde även vara likgiltigt. Om staten lånar direkt $\mathrm{i}$ riksbanken eller i privatbankerna, och dessa sedan i sin tur i riksbanken spelar ju föga roll. För övrigt kan man ju tänka sig en centralbank, som driver affärsbankrörelse, $\mathrm{i}$ vilket fall statens lånekrav kunna fullständigt jämställas med privatas och bankers. Skulle staten själv trycka sedlar, så medför hållandet av normal räntefot, att centralbankssedlarnas kvantitet minskas med samma belopp som statssedlarna växa, varför någon inflation ej framkallas. Sant är visserligen att staten kan trycka så mycket sedlar, att det blir praktiskt onöjligt att draga in motsvarande kvantitet banksedlar eller checkdeposita, liksom staten kan låna så stora belopp $\mathrm{i}$ centralbanken att det blir omöjligt att hålla cirkulationen konstant. Men detta utgör intet argument mot påståendet, att "direkt» inflation är detsamma som »indirekt», utan betyder endast, att inflation i detta läge är oundviklig.

Economic Journal 1917: Inflation, sid. 489. 